International Journal of English Language Studies (IJELS)

ISSN: 2707-7578

DOI: $10.32996 /$ ijels

Website: https://al-kindipublisher.com/index.php/ijels

\title{
Pronunciation Mobile Application for Oral Communication
}

Adrian M. Abarquez

SHS Faculty, University of Cebu-Banilad Campus, Cebu, Philippines

Corresponding Author: Adrian M. Abarquez, E-mail: ucb.adrian@gmail.com

\section{ARTICLE INFORMATION}

Received: December 08, 2020

Accepted: February 14, 2021

Volume: 3

Issue: 2

DOI: $10.32996 /$ ijels.2021.3.2.1

\section{KEYWORDS}

Pronunciation, mobile application, oral communication, quasi-

experimental

\section{ABSTRACT}

English is a basic prerequisite for people to achieve accomplishments in various fields. In today's age, students are well-diverse in eclectic mechanisms to enhance one's English skills. The 21st century learners have embraced the new way of acquiring skills through the combination of internet sources and mobile applications. This research was done at the Advance Institute of Technology (AIT) to assess the efficacy of smartphone pronunciation in oral communication for 10 English. For the control and experimental classes, a quasi-experimental design was used. There were 42 students as subjects in the study. The students answered a twenty-five (25) item oral production questionnaire as a research instrument. Using the required statistical instrument, based on the result of the analysis, the control group had a very good performance on the pretest while a bigger proportion of the experimental group also performs the same while there was one who performed excellently. Hence, with today's young learners who are digital savvy, oral literary skills are best improved when English teachers make use of the most utilized and enjoyed simulations for visual and auditory to enhance pronunciation skill development.

\section{Introduction}

English is a basic prerequisite for people to achieve accomplishments in various fields. In today's age, students are well-diverse in eclectic mechanisms to enhance one's English skills. In doing so, the printed materials have been supplanted with electronic devices and the existence identified with paper perusing have experienced changes. The $21^{\text {st }}$ century learners have embraced the new way of acquiring skills through the combination of internet sources and mobile applications. One of the most significant concepts that emerged inside this setting has been the use of mobile application. Along with its ubiquity and versatility, the mobile phone provides potential benefits for learning foreign languages. First, the device's simplicity, familiarity and practicality pledge successful learning by enabling students to quickly access learning (Hsu, 2012). Also, Oberg and Daniels (2013) have indicated that it allows for self-paced learning, which would increase the amount of personally meaningful discipline, selfefficacy, commitment, and learning.

The internet has gotten one of the most significant sources to give learning references to students to share and get data. Students today are considered "advanced locals" in other words, internet-users who have grown up utilizing innovations. PCs, smart phones and the internet are the examples. In connection, E-learning is an idea that covers a different application, procedure and learning techniques. According to Kumar (2009), e-learning is additionally alluded to the utilization of data and communication advancements to encourage the access to web-based learning and offers a lot of devices and utilities that influence communication and acquiring new learning. Thus, the interest of the students is enhanced through the use of technology since it stimulates one's senses. It gives more freedom to students where access and updates are ubiquitous.

According to Ahn and Lee (2015), the development of the internet technology innovation has given the students an avenue to carry a ton of comfort to their scholarly life. Students can figure out how to adapt such a large number of various things and with the assistance of mobile application. This aims to overcome many difficulties and barriers faced by the English as a Foreign Language (EFL) face-to-face classroom, such as a lack of language acquisition tools, individualized instruction, reviews and collaborations.

K C AL-KINDI CENTER

R D FOR RESEARCH AND DEVELOPMENT

Your gateway to world-class research

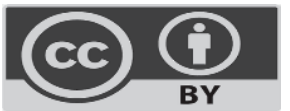

Published by Al-Kindi Center for Research and Development. Copyright (c) the author(s). This open access article is distributed under a Creative Commons Attribution (CC-BY) 4.0 license 
The study plays a big importance since the researcher observed that students have difficulty in shifting their medium of communication from Sinugbuanung-Bisaya (L1) to English language (L2). This reality has awakened the interest of the researcher to direct a formal research keeping in mind the end goal of an answer to the issue. The researcher believes that the school assumes an imperative part in getting the students ready in a responsive and compelling individual.

Moreover, pronunciation plays a role to the students to better bridge one's idea to the listener. Having good pronunciation can eradicate ambiguity in the communication process and give better transition of the topic. As a second language speakers, pronunciation is one of the many skills to be mastered in order to be understood and comprehended by the audience. By knowing this fact, one of the chances to have this study is to enhance the pronunciation of the students as a second language learner. Thus, this study determines the effectiveness of pronunciation mobile application for oral communication.

\section{Theoretical Background}

This study is anchored on the stages of skill acquisition model by J.R. Anderson. Anderson theorized that it is a function of cognitive control of running processes to cultivate a skill. He segments the systems into three phases: the independent, the associative, and the cognitive. Students remember a number of realities important to their potential in the psychological process. He responds to these facts as declarative learning. In the first instance when they act out the skill, students become acquainted with these concepts. The associations between the components needed for fruitful execution are reinforced in the associated stage; errors are separated and dispensed with. The learners carry out the skill easier, quicker, and all the more as a result in the autonomous process. Over decisive data, students have changed into what is called procedural learning, which involves a lower handling cap. The gifted demonstration is controlled by methodical, not revelatory (Anderson, 1995). Thus, this first theory suggested that students best learn through familiarization. By that, students quickly get the processes on how to do it with less assistance of teacher.

The second theory that supports skill acquisition is Virginia Collier's language acquisition for school. Virginia Collier's language acquisition has four parts. These are: sociocultural, scholastic, cognitive, and phonetics. In the case that one is produced to ignore another, this could impede the general creation and potential accomplishment of an understudy. The academic, analytical, and etymological segments must be seen as formative, as well as the systematic tutoring phase for the tyke, youthful and youthful grown-up. The development of one of these three components is basically dependent on the synchronous transformation of the other two, both in the first and second languages (Collier, 1995).

In sociocultural scholastic, Collier (1995), the learning of language by the student is all of the social and cultural phenomena that exist in daily life in the context, present and future of the student, in all contexts at home, education, culture and the larger society. As the second component of the theory of language learning, linguistic structures consist of the tacit elements of the production of language (the fundamental ability of all people to acquire oral language), as well as the metalinguistic, active, standardized teaching of language at school and the acquisition of a written system of language.

This entails acquiring the first and second languages of the student's oral and written systems across both language fields, such as the different macro linguistics. The first language structure of a student, oral and written, must be built to a high cognitive standard, at least during the primary school years, to ensure cognitive and academic performance in a second language (Collier, 1995).

The model's third dimension, academic progress, involves all school work at each grade level in language arts, mathematics, science, and social sciences. K-12 grades and beyond. Academic research significantly extends the vocabulary, sociolinguistic, and discourse aspects of language to greater cognitive levels for each subsequent ranking. The change from the first language to the second language in cognitive learning and student growth is even more successful when studying the second language by substantive learning exercises at other times of the school day, to enhance academic work through the first language of the students.

Thus, this theory focused on developing one's cognitive level thru practice from what is learned in first language to second language. Align with this, the use of pronunciation mobile application enhances the oral communication of the students.

The third theory that supports skill acquisition is observational learning by Albert Bandura.It is fundamental to a range of significant issues related to the degree to which individuals simply learn by watching others' behaviour. Three basic models of observational adaptation were recognised by Bandura and Walter (1977): (1) a live model involving a specific participant exhibiting or showing a behavior; (2) a verbal teaching model featuring representations and examples of a behavior; and (3) a symbolic model involving actual or anecdotal characters displaying acts in books and movies. 
Observational experience, which should be apparent, does not even fundamentally involve observing someone else taking part in an event. Hearing verbal instructions will prompt learning, for instance, tuning in to a data communication. We may also learn by examining, listening to, or witnessing the actions of characters in books and films.

According to Stone (2017), the first condition for observational learning is attention. If a person is going to learn more from a model, he or she must pay attention to it and the actions it demonstrates, and there are many variables that may influence the attention of its observer. Thus, making motivation as the most aspect of observational learning.

Thus, this theory gives a logical explanation that students learn in looking and observing different illustrations and ways presented by the mobile application with teacher's assistance. With this, the strategy used give accurate ways in pronouncing the given words to have a better oral context.

Hence, the cited theories are valid based on the formulation of the problem and implications of findings. With this premise, the pronunciation mobile application as teaching strategy in oral communication by the three theories cited above.

\section{Research Problem}

This study determined the effectiveness of pronunciation mobile application for oral communication, grade 10 students, Advance Institute of Technology (AIT), Lapu-Lapu City, S.Y. 2018-2019. The results of the study were the bases for a proposed action plan.

Specifically, this study sought to address the following questions:

a. What are the control and experimental groups' pretest performances?

b. What are the control and experimental groups' posttest performances?

c. Is there a significant difference between the control and experimental groups' the pretest performances?

d. Is there a significant difference between the control and experimental groups' pretest and posttest performances?

e. Is there a significant difference between the control and experimental groups' the posttest performances?

f. What action plan may be proposed on the basis of the findings?

\section{Literature Review}

Mobile technology has been rising rapidly. More than ever, it must be conceived as a complex, and cumulative process that takes place during life in correlation with learning. According to Falk and Dierking (2000), learning is an aggregation of real-life experiences, not an abstract experience that occurs in isolation. It is anchored on the construction of collated knowledge and assimilation of information through observations or mobile applications. Ergo, people learn through direct experience with both intrinsic and extrinsic motivations to activate learning process.

Mobile learning concerns the production of knowledge using a mobile device ( $m$-learning). This technology has created the ability to create learning environments in line with the standards of constructivism, in which learners are relational and selfmanaged. (2003, Mayer).

According to Fransen (2008), the possible benefits and drawbacks of mobile learning are discussed in an outline. One of the biggest benefits is knowing what, where, when and how can a mobile device be of an integration in learning process. In doing so, Norbrook and Scott (2003) elucidate that the fact that device is still accessible anywhere you choose to use, it is the most inviting attribute when using mobile devices.

The efficiency of mobile apps is well known by Kukulska-Hulme and Shield (2008). In explicit and implicit settings, mobile learning, both in the classroom and outdoors, can take place. In contrast, however, we find that these are mainly text-based when we look at existing mobile applications for language learning (Kukulska-Hulme \& Shield, 2008) and the application of the intellectual tutoring model (Bull, 1994: Chen \& Chung, 2008: Collins, 2005: Thornton \& Houser, 2005). The mobile applications are optimized at the high school level for adult users.

The cited related literature gives an overview of the existence of mobile application in learning process. It presents eclectic advantages and disadvantages of the trend in the education. Hence, mobile devices direct an active role in honing one student's pronunciation to oral communication.

Pronunciation mobile application is a specific tool in developing students' pronunciation towards effective oral communication. It utilizes both mobile cellular phones and internet connection. According to Tan and Liu (2004) on the mobile-based digital learning experience (MOBILE) and a case study to support English elementary school learning, cell phones were used to enable students to learn articulation efficiently. There are a few highlights, for example, the revision, an intriguing user interface (UI), and 
the reasonable direction that causes the students to do oneself learning. The students need not bother with an educator to manage them. Learning the elocution utilizing a cell phone will help the students since it facilitates them to learn and rehearse the articulation all over the place and anyplace.

In the study of Thornton and Houser (2005) on using mobile phones in English education in Japan revealed that getting data about their classes by means of cell phones is of significant potential use. At the point when really utilizing instructive materials intended for cell phones, students assessed them decidedly, and test outcomes demonstrated that they had the option to learn by means of this medium. One's examinations propose cell phones can be compelling instruments for an expansive scope of instructive exercises.

Also, another study that expresses the effectiveness of mobile application is from Saran, Seferoglu and Cagiltay (2009) on mobile assisted language learning: English pronunciation at learners' fingertips expressed that students claim and every now and again utilize cell phones in their lives. This study broadens the utilization of cell phones, which are as of now utilized for correspondence and stimulation, to instruction. The results of this study suggest that using mobile phones in classroom contexts will help students feel more empowered and promote the experience of the teacher or parent to tackle the shortcomings in order to get students to start training.

According to Baleghizadeh and Oladrostam (2010) on their study, the effect of mobile assisted language learning (MALL) on grammatical accuracy of students from the EFL have concluded that cell phones will play a key role in enhancing students' speech content. Another factor worth noting is an effort to assist teachers, especially English teachers in developed countries, who do not have ample opportunities in their classrooms to use advanced technology. Teachers will be able to give their students input and draw about their speech concerns outside the classroom in this manner.

A study of Kim and Kwon (2012) on exploring smartphone applications for effective mobile-assisted language learning utilized cell phone applications for ESL classes. First, the larger part of users manage short language information data, for example, word records, elocutions, syntactic components, or test discourse or papers and so on. In this way, a large portion of the applications present language learning of lexical level or encourage the clients with glossaries regularly including one-sentence models or articulation sound records. The successful plan and utilization of ESL versatile applications should keep on being contemplated so as to propose the correct course to powerful mobile assisted language learning.

Yang (2013) on mobile assisted language learning: review of the recent applications of emerging mobile technologies believed that stationary learning assistants are moved to mobile devices, enabling language learning to be independent of any time and venue. Both PCs and apps for mobile devices will potentially take place concurrently. Multi-functional mobile devices can lead to a more comprehensive instructional experience for language learners, as can be seen above in examples of mobile aided language learning (MALL) apps.

Kim (2013) on emerging mobile apps to improve English listening skills stated that a large portion of the educators come up short on the capacity to adjust cell phones on showing materials or create easy to use m-learning instruments or advanced mobile phone applications for educational purposes. In light of that, in this way, a well-structured instructional devices and applications ought to be created.

According to Ahn and Lee (2015) on their study, a mobile-based English-speaking application described by the user interface of a mobile-speaking application with automated speech recognition for EFL learning extended the possibilities for communicating beyond the face-to-face-speaking practice of the classroom. The smartphone app, which made the process of speaking more interactive, fun and inspiring. By using contextualized language learning, the scenario-based exercises engaged the students and provided more authentic chances for communicating. Wang (2015) also concluded on a constructivism-based smartphone framework for EFL vocabulary learning that it is obvious that the using mobile application enabled learners to be actively involved in the learning process of constructing word knowledge and the review parts based on spaced encounters promoted learners' language enhancement both in pronunciation and vocabulary.

According to Cavus (2016) on development of an intelligent mobile application for teaching English pronunciation, advances in innovation has brought about the improvement of intelligent cell phones. This has attracted the enthusiasm of scientists' studying in the field of education uniquely in showing unknown dialects. What's more, the students who need to improve their pronunciation may locate the created intelligent portable application valuable and pleasant to utilize. In doing so, Bradley (2015) on the mobile language learner-use of technology in language learning observed that cell phones have a bearing on the instruction. 
Mutqiyyah and Muhammad (2016) on developing mobile app of English pronunciation test using android studio utilized a mobile application as a back to back work process, a great of lay-trip content situation, and it has an unmistakable direction to run the application. Students like to learn elocution through application than direct from the educator or site.

According to Hazaea and Alzubi (2016) on their study, the effectiveness of using mobile on EFL learners' reading practices in Najran University observed that the pedagogical use of cell phones and the availability of unique language learning experiences is pedagogical. Students are no longer limited to the conventional classroom, but due to smartphone features, they have advantageously spread their learning beyond the classroom; mobile online and offline dictionaries have been used for pronunciation within and outside the classroom.

Further, a study of Gangaiamaran and Pasupathi (2017) on review on use of mobile apps for language learning discovered cell phones, iPods, and iPods have improved self-managed learning. These gadgets are effective for their utilization in learning the language. Future studies should include how, from the viewpoint of self-getting to studying, flexible implementations should be considered. Students chose what they understand, how they read, and how they interpret their own learning for themselves. The students will decide when and where to learn through the use of online assets by self-getting to learning.

The cited related studies give a clinching idea of the use of mobile application in teaching-learning process. This insinuates a conclusive idea that enhancing new skill is through the incorporation of innovation such as mobile phones and tablets. In line with this, the results above confirm that adapting a new way of learning is beneficial in honing ones' skill like in pronunciation. However, there are existing gaps in the body of literature and the researcher wants to fill in these academic gaps. With this notion, the researcher wants to determine the effectiveness of pronunciation mobile application in enhancing students' oral communication among junior high school students. In doing so, the study further gives an insight in venturing on the "Pronunciation Mobile Application for Oral communication. Therefore, the realization of this study will be beneficial to both students and English teachers. They may utilize pronunciation mobile application in eclectic speaking activities to further enhance one's oral communication.

\section{Methodology}

This study utilized a quasi-experimental design under quantitative approach using pronunciation mobile application. The subjects of the study were forty-two (42) grade 10 students and were divided equally based on their age, gender, and grade 9 final English grades in Advance Institute of Technology (AIT). Twenty-one (21) students served as control group and the other twenty-one (21) students as the experimental group. The researcher utilized a researcher-made pronunciation test. Words and phrases were selected from a story entitled "A Letter to an Unborn Son" by an unknown Yugoslavian soldier. There were twentyfive (25) items in the test questionnaire. The 3 inter-raters will accumulate the scores to seventy-five (75) as a perfect score.

A letter requesting for authorization to conduct this study was sent to the school registrar, junior high school coordinator, and high school principal. The request was affirmed by the said party which likewise empowered the researcher to gain access to students' records and different documents supportive to the procedure. The teacher had a diagnostic examination about the fourteen vowel sounds. As research proceeded until conducting the pretest and posttest to the control and experimental subjects, the weakest produced sounds became the objective. The pronunciation mobile application named Pronounce was personally given to the experimental group and had been integrated within the students' regular English course. The selected students in experimental group had given a task to introduce the pronunciation mobile application to the students who were in the control groups. A posttest using the same tool in the pretest was administered in the quasi-experimental study.

In point one, the experimental group was engaged in oral production test. Students produced the proper sound using their

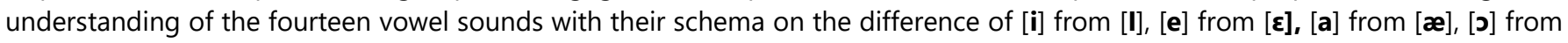

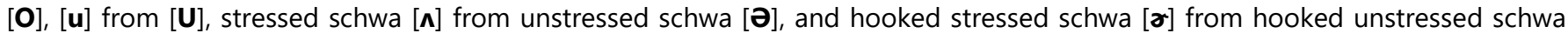
[3]. In point two of the quasi-experimental study was the actual implementation of the pronunciation mobile application in improving pronunciation. The teacher introduced an integration of the pronunciation mobile application in improving pronunciation of the students. The goal was to let them master the vowel sounds based on the pilot test. After, the students were assessed through oral test with the same questionnaire. The result served as basis for the proposed action plan. The data gathered were treated for tabulation, statistical analyses and interpretation. The result served as a basis for a proposed action plan. 


\section{Results and Discussion}

Control and Experimental Group's Pretest Performance

Table 1. Control and Experimental Group's Pretest Performance

\begin{tabular}{c|ccc|ccc}
\hline \multirow{2}{*}{$\begin{array}{c}\text { Range of } \\
\text { Scores }\end{array}$} & \multicolumn{3}{|c|}{ Control Group } & \multicolumn{2}{c}{ Experimental Group } \\
\cline { 2 - 6 } & $\begin{array}{c}\text { No. of } \\
\text { Students }\end{array}$ & $\%$ & $\begin{array}{c}\text { Level of } \\
\text { Performance }\end{array}$ & $\begin{array}{c}\text { No. of } \\
\text { Students }\end{array}$ & $\%$ & $\begin{array}{c}\text { Level of } \\
\text { Performance }\end{array}$ \\
\hline $61-75$ & 13 & 62 & Very Good & 15 & 5 & Excellent \\
$46-60$ & 6 & 29 & Good & 5 & 24 & Very Good Good \\
$31-45$ & 2 & 9 & Poor & & \\
$16-30$ & & & & & \\
$1-15$ & & & &
\end{tabular}

Table 1 shows that a greater majority (62\%) of the students in control group has a very good performances on the pretest while a bigger proportion (71\%) of the experimental group also performs the same while one (5\%) performs excellently. The results of pretest performances of control and experimental groups is supported by Anderson (1995), where the students have a schema of the lesson that applies real-life context situation. Also, in their learning, the teacher gives procedures on how to handle the given information.

\section{Control and Experimental Group's Posttest Performance}

Table 2. Control and Experimental Group's Posttest Performance

\begin{tabular}{|c|c|c|c|c|c|c|}
\hline \multirow{2}{*}{$\begin{array}{c}\text { Range of } \\
\text { Scores }\end{array}$} & \multicolumn{3}{|c|}{ Control Group } & \multicolumn{3}{|c|}{ Experimental Group } \\
\hline & $\begin{array}{c}\text { No. of } \\
\text { Students }\end{array}$ & $\%$ & $\begin{array}{c}\text { Level of } \\
\text { Performance }\end{array}$ & $\begin{array}{c}\text { No. of } \\
\text { Students }\end{array}$ & $\%$ & $\begin{array}{c}\text { Level of } \\
\text { Performance }\end{array}$ \\
\hline $61-75$ & 5 & 24 & Excellent & 19 & 86 & Excellent \\
\hline $46-60$ & 12 & 57 & Very Good & 2 & 14 & Very Good \\
\hline $31-45$ & 4 & 19 & Good & & & \\
\hline $16-30$ & & & Poor & & & \\
\hline $1-15$ & & & & & & \\
\hline
\end{tabular}

Table 2 shows that majority (57\%) of the control group has a very good performances on the pretest and a noticeable (24\%) proportion performs excellently while $86 \%$ of the experimental group perform excellently and $14 \%$ perform very good.

Most of the students in the experimental group performed well because they were exposed on the aide of pronunciation mobile application where students are engaged now in new ways of acquiring and enhancing new learning. On the other hand, the students in control group had an independent learning which is less teacher-student centered. This idea can be supported by Perez (2002) who cited that innovation in acquiring learning is one of the effective instructional viabilities. These catch students' advantage, support cooperation and continued consideration, hence coming about to effective communication among students and instructors. Also, the result is supported by Hazaea and Alzubi (2016) who strongly believed that it is advantageous for the students to extend their learning outside the classroom thru the use of mobile application.

Control and Experimental Groups' Difference between the Pretest Performances

Table 3. Control and Experimental Groups' Difference between the Pretest Performances

\begin{tabular}{ccccc}
\hline Pretest Scores & Computed t-test & p-Value & Decision of Ho & Interpretation \\
\hline $\begin{array}{c}\text { Control Group } \\
\begin{array}{c}\text { Experimental } \\
\text { Group }\end{array}\end{array}$ & -1.84 & & Accept Ho & $\begin{array}{c}\text { No significant } \\
\text { difference }\end{array}$ \\
\hline
\end{tabular}

Table 3 indicates that there is no substantial gap in the results of the oral speech pre-test performed by the control and experimental classes. It was also observed that the pre-test performance of the control subjects did not vary substantially from the pre-test performance of the experimental group. Because their pre-test performance does not differ substantially, the two 
groups are paired in terms of entry qualifications, and hence the pre-post quasi-experimental method is optimal for the control group.

Control and Experimental Groups' Difference between the Pretest and Posttest Performances

Table 4. Control and Experimental Groups' Difference between the Pretest and Posttest Performances

\begin{tabular}{llccc}
\hline \multicolumn{1}{c}{ Variables } & Computed t & p-value & $\begin{array}{c}\text { Decision on } \\
\text { Ho }\end{array}$ & Interpretation \\
\hline - $\begin{array}{l}\text { Pretest of the control and } \\
\text { experimental groups }\end{array}$ & -1.84 & .07 & Accept & $\begin{array}{c}\text { No significant } \\
\text { difference }\end{array}$ \\
- $\begin{array}{l}\text { Pretest and posttest of the } \\
\text { control group }\end{array}$ & -11.35 & $3.63 E-10$ & Reject & $\begin{array}{l}\text { Significant } \\
\text { difference }\end{array}$ \\
- $\begin{array}{l}\text { Pretest and posttest of the } \\
\text { experimental group }\end{array}$ & -16.51 & $4.05 E-13$ & Reject & $\begin{array}{l}\text { Significant } \\
\text { difference }\end{array}$ \\
- $\begin{array}{l}\text { Posttest of the control and } \\
\text { experimental groups }\end{array}$ & -5.80 & $3.15 E-06$ & Reject & $\begin{array}{l}\text { Significant } \\
\text { difference }\end{array}$
\end{tabular}

$\alpha=.05$

Table 4 shows that the pre-test performance of the control and experimental groups does not differ substantially, as previously stated; it shows that in terms of entry performance, the two groups are equal. This is important to ensure that the matching remains accurate and that the design is still applicable to a control group being presented. In this case, it is relevant.

On the other hand, the pretest and posttest performances of the control group significantly differ. So, despite not experiencing the Pronounce mobile application, they were able to get better in the posttest. This implies familiarity of the test.

But it is found that there is a substantial improvement in the experimental group's posttest scores. This indicates that the smartphone device Pronounce has helped a lot in optimizing the scores of the experimental group subjects.

Likewise, the post-test gains of the control and experimental classes vary considerably. Thus, the Pronounce mobile application is effective in improving oral communication.

The results of the pretest and posttest performances of experimental group is supported by Mutqiyyah and Muhammad (2016), where the utilization of mobile application in learning process create an invitation to the students to learn and explore than a teacher-centered discussion. Also, Gangaiamaran and Pasupathi (2017) believed that using innovation such as mobile application in learning pronunciation is effective for students' utilization in learning correct pronunciation. Moreover, students can have an access anytime and anywhere since it is readily available in the smartphones. Thus, using the Pronounce mobile application can really make an impact in improving the efficacy of oral communication.

Control and Experimental Groups' Difference between the Posttest Performance

Tables 5. Control and Experimental Groups' Difference between the Posttest Performance

\begin{tabular}{ccccc}
\hline Posttest Scores & Computed t-test & p-Value & Decision of Ho & Interpretation \\
\hline $\begin{array}{c}\text { Control Group } \\
\text { Experimental }\end{array}$ & -5.80 & $-3.15 E-10$ & Reject Ho & $\begin{array}{c}\text { Significantly } \\
\text { different }\end{array}$ \\
\hline Group & & & & \\
\hline
\end{tabular}

Table 5 indicates that the research findings showed that there is a substantial gap between the control and experimental groups' posttest performance. The finding on the conclusions suggested that it should be rejected.

The significant difference of the two groups' performances would prove consistent of Yang (2013) in which he believed that stationary learning can be transferred to new innovation which is mobile application which enable the students to have an independent learning from any time and location. Also, this is supported by Wang (2015) who concluded that smartphone application encourages students to be fully engaged in the learning process and to develop their pronunciation skills in English. It is noted that the post-test scores of the experimental group have substantially improved. This indicates that the smartphone device Pronounce has helped a lot in boosting the scores of the experimental subjects. Likewise, the post-test gains of the control and experimental groups vary considerably. 
This also shows that the smartphone application of Pronounce is successful in improving students' oral communication skills. This may be further repeated in other speech classes.

\section{Conclusion}

This study determined the effectiveness of pronunciation mobile application for oral communication, grade 10 students, Advance Institute of Technology (AIT), Lapu-Lapu City, S.Y. 2018-2019. The results of the study were the bases for a proposed action plan. This study utilized a quasi-experimental design under quantitative approach using pronunciation mobile application. The subjects of the study were forty-two (42) grade 10 students and were divided equally based on their age, gender, and grade 9 final English grades in Advance Institute of Technology (AIT). Twenty-one (21) students served as control group and the other twenty-one (21) students as the experimental group. The researcher utilized a researcher-made pronunciation test. Words and phrases were selected from a story entitled "A Letter to an Unborn Son" by an unknown Yugoslavian soldier. There were twentyfive (25) items in the test questionnaire. The 3 inter-raters will accumulate the scores to seventy-five (75) as a perfect score.

Using the required statistical instrument, based on the result of the analysis, the control group had a very good performance on the pretest while a bigger proportion of the experimental group also performs the same while there was one who performed excellently. The result signifies that the result is fit to enhance student's oral communication skills. Therefore, the result of this study leads to identification of more innovative methods in teaching English speech and communication classes, which is expected to increase students' participation and interest.

Limitations attempt to recognize the study's possible weakness. The lack of literature showed that there was no prior local and national analysis of this subject. This limitation had an effect on the pacing of the researcher as the researcher needed ideas to help its reliability and validity. For the study's success, the researcher ensured that he was versatile and sensitive to the situation.

Thus, the researcher concluded with today's young learners who are digital savvy, oral literary skills are best improved when English teachers make use of the most utilized and enjoyed simulations for visual and auditory to enhance pronunciation skill development.

\section{Recommendation}

Based on the findings, the researcher recommends a pronunciation mobile applications workshop for teachers. This will be a great help for teachers who want to make their students love pronunciation and speaking classes or activities and at the same time be engaged in the fullness of academic learning outcome. The pronunciation mobile applications are the following:
a. Pronounce mobile application
b. English Pronunciation: Offline, Pitch, Speech Rate
c. Speak English Pronunciation
d. American English Pronunciation
e. Pronounce English Correctly

\section{References}

[1] Ahn, T. \& Lee, S. (2015). User experience of a mobile speaking application with automatic speech recognition for EFL learning. British Journal Of Educational Technology.

[2] Anderson, J. R. (1995). Cognitive psychology and its implications. New York: W. H. Freeman and Company.

[3] Baleghizadeh, S. \& Oladrostam, E. (2010). The effect of mobile assisted language learning (MALL) on grammatical accuracy of EFL students. Mextesol Journal.

[4] Bandura, A. \& Walters, R. H. (1977). Social learning theory. Englewood Cliffs, NJ: Prentice-Hall.

[5] Bradley, L. (2015). The mobile language learner-use of technology in language learning. J. UCS, 21(10).

[6] Bull, S. (1994). Student modelling for second language acquisition. Computers \& Education, 23(1-2), 13-20.

[7] Cavus, N. (2016). Development of an intellegent mobile application for teaching English pronunciation. Procedia Computer Science.

[8] Chen, C.M., \& Chung, C.J. (2008). Personalized mobile English vocabulary learning system based on the item response theory and learning. Language Learning \& Technology.

[9] Collier, V. P. (1995). Acquiring second language at school. Washington, DC: National Clearinghouse for English Language Acquisition.

[10] Collins, T. (2005). English class on the air: mobile learning with cell phones. In Proceedings of the fifth IEEE international conference on advanced technologies.

[11] Fransen, J. (2008). Mobile Learning: an exploration; State of the art and expectations for the near future. Technical Report.

[12] Gangaiamaran, R., \& Pasupathi, M. (2017). Review on use of mobile apps for language learning. International Journal of Applied Engineering Research, 12(21), 11242-11251.

[13] Hazaea, A. N. \& Alzubi, A. A. (2016). The Effectiveness of Using Mobile on EFL Learners' Reading Practices in Najran University. English language teaching. 
[14] Hsu, L. (2012). English as foreign language learner's perception of mobile assisted language learning: a cross-national study. ComputerAssisted Language Learning.

[15] Kim, H. \& Kwon, Y. (2012). Exploring smartphone applications for effective mobile-assisted language learning. Multimedia-Assisted Language Learning.

[16] Kim, H. S. (2013). Emerging mobile apps to improve English listening skills. Multimedia-Assisted Language Learning, 16(2), 11-30.

[17] Kukulska-Hulme, A., \& Shield, L. (2008). An overview of mobile assisted language learning: from content delivery to supported collaboration and interaction. ReCALL.

[18] Kumar, Rupesh A. (2009). E-learning 2.0: Learning Redefined. Library Philosophy and Practice (e-journal).

[19] Mayer, R. (2003). The promise of multimedia learning: using the same instructional design methods across different media. Learning and instruction.

[20] Mutqiyyah, R. \& Muhammad, A. F. (2016, September). Developing mobile app of english pronunciation test using android studio. In 2016 International Electronics Symposium.

[21] Norbrook, H., \& Scott, P. (2003). Motivation in mobile modern foreign language learning. In J. Attewell, G. D. Bormida, M. Sharples, \& C. Savill-Smith (eds), MLEARN: Learning with mobile devices. London. Learning and Skills Development Agency.

[22] Oberg, A., \& Daniels, P. (2013). Analysis of the effect a student-centred mobile learning instructional method has on language acquisition. Computer assisted language learning, 26(2), 177-196.

[23] Saran, M., Seferoglu, G. \& Cagıltay, K. (2009). Mobile assisted language learning: English pronunciation at learners' fingertips. Eurasian Journal of Educational Research.

[24] Stone, S. (2017). Observational learning. Encyclopedia Britannica Inc.

[25] Tan, T. H. \& Liu, T. Y. (2004). The Mobile-Based Interactive Learning Environment (MOBILE) and a case study for assisting elementary school English learning, Advanced Learning Technologies.

[26] Thornton, P. \& Houser, C. (2005). Using mobile phones in English education in Japan. Journal of Computer Assisted Learning.

[27] Wang, F. (2015). Constructivism-based mobile application for efl vocabulary learning. Sutir.sut.ac.th.

[278 Yang, J. (2013). Mobile Assisted Language Learning: Review of the Recent Applications of Emerging Mobile Technologies. English Language Teaching. 